\title{
Enforcing the economic, social and cultural rights in the African Charter on Human and Peoples' Rights: Twenty years of redundancy, progression and significant strides
}

\author{
Christopher Mbazira ${ }^{*}$ \\ Lecturer, Faculty of Law, Makerere University; Advocate of the High Court of \\ Uganda and PhD research fellow, Socio-Economic Rights Project, Community \\ Law Centre, University of the Western Cape, South Africa
}

\section{Summary}

The fight against poverty and underdevelopment in Africa is amongst others dependent on how successfully the socio-economic rights protected in both the regional and universal instruments are concretised. The last 20 years since the adoption of the African Charter show a slow but steady move towards such concretisation. The African Commission has moved from a stage of redundancy, when not much was done to give normative content to the rights, to a stage of progression, in which the African Commission has started giving content to the rights. In spite of this, the recommendations of the African Commission are yet to be taken seriously not only by state parties, but by the African Union. There is no reliable mechanism to enforce the recommendations of the African Commission and, as the African Court on Human and People's Rights begins operation, its success is likely to be hampered by the same problem. This is in spite of the fact that the African Court has a wide remedial mandate in comparison to the African Commission. As the African Court propels the African human rights system into a stage of significant strides, this is the biggest obstacle in its way. The

* $\quad$ LLB (Makerere), (Dip LP) (LDC), LLM (Human Rights and Democratisation in Africa) (Pretoria); bazzira@yahoo.co.uk. I would like to express my appreciation to Prof Sandra Liebenberg for her insightful comments which I believe greatly improved this paper. At the same time I would like to thank my colleague, Dr Lilian Chenwi, and the anonymous referee for their very useful comments. Mistakes and omissions remain mine. Thanks also to the Community Law Centre and all its donors for the excellent research facilities at the Centre. 
African Union is central in sanctioning states that fail to implement the judgments of the African Court. However, history shows that the Assembly of Heads of State and Government has always been reluctant to sanction its members. Unless there is a change of heart and more commitment to human rights, this practice is likely to persist and thereby negatively impact on the rights protected by the African Charter.

\section{Introduction}

Africa's trademark as a continent is punctuated by poverty, ignorance, diseases and a high level of underdevelopment not comparable to other continents. Poverty in Africa has been described as a harsh reality that translates into half the population living on less than one dollar a day; not having access to safe drinking water; and more than two million infants dying annually before reaching their first birthday. ${ }^{1}$ Recent statistics show a very wide gap in life span between African and European countries: Zimbabwe at 37,9, Zambia at 39 and Angola at 39,9. On the other side of the spectrum, Switzerland is at 80,6 , Sweden at 80,4 and France at $79,7 .^{2}$

Africa's poverty has been exacerbated by the HIV/AIDS epidemic; out of the 38,6 million people living with HIV/AIDS worldwide, 24,5 million are in sub-Saharan Africa. ${ }^{3}$ This epidemic has contributed to the decline in the state of health and increased mortality rates of many Africans; it has also contributed to unemployment arising from physical incapacity and the consequential loss of income. Household savings have been depleted to access care for the sick and income inflows cut off due to sickness and attending to the sick. ${ }^{4}$ Governments have been forced to divert resources that would have otherwise been used for developmental and other health purpose towards the fight against the epidemic. ${ }^{5}$ It is in this context that the protection of economic, social and cultural

UNDP The primacy of pro poor policies for growth http://www.undp.org/rba/ poverty.html (accessed 5 June 2006).

2 'AIDS is cutting African life span to 30 year low, report says' The New York Times 6 June 2006.

3 UNAIDS 2006 Report on the global AIDS epidemic $13 \mathrm{http} / /$ www.unaids.org/ en/ HIV data/2006GlobalReport/default.asp (accessed 7 June 2006) 4. The report also shows that in the last 25 years, close to 40 million children have been orphaned by AIDS.

4 Uganda AIDS Commission 'HIV/AIDS in Uganda' http://www.aidsuganda.org/ (accessed 13 June 2006).

5 Eg, the National Strategic Framework for HIV/AIDS Activities in Uganda: 2000/1 $2005 / 6$ projected that of 3,3\% of government expenditure would be on HIV/AIDS; see D Ddamulira HIV/AIDS spending study International component: The case of Uganda (2002) $12 \mathrm{http}: / /$ www.idasa.org.za/ gbOutputFiles. asp?WriteContent=Y\&R ID=649 (accessed 16 June 2006). 
rights (socio-economic rights) ${ }^{6}$ on the continent should be understood. ${ }^{7}$

This paper sets out to review the approach of the African Commission on Human and Peoples' Rights (African Commission) in enforcing the socio-economic rights protected by the African Charter on Human and Peoples' Rights (African Charter) ${ }^{8}$ in the 20 years since it entered into force. The approach of the African Commission has occurred in two stages, the first stage being the 'redundancy' stage and the second the 'progression' stage. The first stage describes that period in time when very little was done in developing the normative content of the rights and elucidating on the obligations they engender. The second stage represents a period when the African Commission started giving content to the rights and construing the obligation they engender. The stage of 'significant strides' is only prospective and premised on the potential success of the African human rights system as seen through the prism of the African Court on Human and Peoples' Rights (African Court).

The contribution of this paper is not only its description of the stages defined above, but its account of the factors dictating the direction of the stages. The paper places the stages in context by tracing the genesis of socio-economic rights in Africa and briefly describing their nature in the African Charter. The stages are described by using examples of some of the major communications decided by the African Commission in the respective stages. The paper also highlights some of the obstacles likely to be encountered by the African Court as it propels socio-economic rights into a third stage of significant strides.

\section{The genesis of socio-economic rights in Africa}

Events and ideological developments that preceded the adoption of the African Charter are important in understanding the justification for the inclusion of socio-economic rights in this instrument. When Africa emerged from colonial rule in the early 1960s, there was consensus that the 'independent state' should assume the responsibility of cham-

6 The term 'socio economic rights' is used for convenience purposes. It is not in any manner intended to undermine the importance of cultural rights and their position as part of the African Charter. Later in this article I give examples of African cultural practices that have relevance in respect of the enjoyment of socio economic rights.

7 Though undocumented as human rights abuses, violations of the rights to health, education, food, water, housing, environment and social security have taken place in Africa on a large scale; N Udombana 'Towards the African Court on Human and Peoples' Rights: Better late than never' (2000) 3 Yale Human Rights and Development Law Journal 45.

8 Adopted on 27 June 1981 by the OAU Assembly of Heads of State and Government in Nairobi, Kenya OAU Doc CAB/LEG/67/3 rev 5, (1982) 21 International Legal Materials 58, entered into force 21 October 1986. 
pioning rapid political, social and economic reforms. The colonial state had been exploitative, large-scale exploitation of natural resources had taken place but not much returned to the Africans in the form of socioeconomic development. ${ }^{9}$ According to Oliver and Atmore, ${ }^{10}$ the colonial state felt that its main duty in Africa was to maintain law and order and to do so without expense to the European taxpayer. They cite education as an example; it was left to the private enterprises of church missions. To maintain law and order, as was perceived by the colonial government, required adoption of draconian laws that intruded on all aspects of African life. It is therefore not surprising that the state was characterised by massive violation of civil and political rights. ${ }^{11}$ On the economy side, there is no doubt that colonialism fast-tracked Africa's integration in the global economy. But as argued by Mamdani, this integration was one-sided and outward-looking, the economies were groomed as crop exporters and importers of necessaries which created dependence. ${ }^{12}$ Mdani also demonstrates how the colonial economy denied Africans self-sustenance and made them dependent on the economy which came with several impositions that further impoverished the African. ${ }^{13}$

As one scholar has put it, 'African states with their inherited weak economies thought their primary task was to overcome poverty, disease, malnutrition, illiteracy, etc. ${ }^{14}$ The post-colonial African leaders have persistently resisted human rights as an agent for human development. They believe that what Africa needs are sound economic policies implemented without detractions created by notions of human rights. But in spite of the enforcement of several economic policies on the continent, self-sustenance has not be realised. The problem with the independent African state is that it has recycled and used in the same manner the relationship of subjection, as described by Mbembe, ${ }^{15}$ between itself and the state as was created by colonialism.

Unless economic policies integrate the African individual in its making, give him or her a voice and improve his or her socio-economic wellbeing, the policies remain tools of white collar debate. The African peasantry can only be empowered to participate in this debate and

9 J Oloka Onyango 'Beyond the rhetoric: Reinvigorating the struggle for economic and social rights in Africa' University of Minnesota Human Rights Library http:// www1.umn.edu/humanrts/africa/Oloka Onyango.html (accessed 20 June 2006).

10 R Oliver \& A Atmore Africa since 1800 (1994) 124.

11 For a detailed account of the extent of human rights violations by the colonial state, see $\mathrm{V}$ Nmehielle The African human rights system: Its laws, practice and institutions (2001) 1729.

12 M Mamdani Citizen and subject: Contemporary Africa and the legacy of later colonialism (1996) 145.

13 n 12 above, 6147.

14 E Ankumah The African Commission on Human and Peoples' Rights: The practice and procedures (1996) 5.

15 A Mbembe On the post colony (2001) 34. 
influence its direction in their favour if they are empowered through human rights norms. Emphasis on public wellbeing in white collar debates tends to alienate the individual and his needs; an equitable balance should be made between the requirements of the public well-being and the rights of the individual. ${ }^{16}$ This can be done through provisions that protect both collective and individual socio-economic rights and integrate them as part of policy conception and implementation.

\section{Towards the African Charter on Human and Peoples' Rights}

Express references to the need to protect socio-economics emerged from two colloquiums held in 1978: the Butare Colloquium ${ }^{17}$ and the Dakar Colloquium, ${ }^{18}$ both on human rights and development. The participants at the Butare Colloquium discussed the relationship between human rights and development and concluded that the lack of resources in many African countries did not justify lack of respect for civil and political rights and for socio-economic rights. ${ }^{19}$ At the Dakar Colloquium, it was concluded that human rights could not be reduced to civil and political rights, socio-economic rights needed particular attention as the rights were mutually interdependent. ${ }^{20}$ Subsequent efforts, initiated mainly by the United Nations (UN) Commission on Human Rights, directed to establishment of a human rights system for Africa failed, mainly because of the reluctance of African leaders to cede their sovereignty to a system of human rights. ${ }^{21}$

However, calamitous events, especially in the 1970s, leading to the rise of dictatorships in some African countries, drew the Organization of the African Unity (OAU), now the African Union (AU), to accepting that there was a need to protect human rights on the continent. At its 16th ordinary session, 16 to 20 July 1979, the OAU Assembly of Heads of State and Government expressed its commitment to the protection of

\footnotetext{
16 First Conference of French Speaking African Jurists, held in Dakar, Senegal 59 January 1967, 5, as quoted by F Ouguergouz The African Charter on Human and Peoples' Rights: A comprehensive agenda for human dignity and sustainable democracy in Africa (2003) 21.

17 Human Rights and Economic Development in Francophone Africa, a colloquium organised by the Institute of International Law and Economic Development (Washington DC) and the Faculty of Law of the National University of Rwanda 37 July 1978; see Ouguergouz (n 16 above) 2324.

18 Organised by Association Sénégalaise d'Études et de Recherches Juridiques and by the International Commission of Jurists, September 1978; see Ouguergouz (n 16 above) 24.

19 Ouguergouz (n 16 above) 24.

20 Ouguergouz (n 16 above) 25.

21 Nmehielle (n 11 above) 70; see also Ankumah (n 14 above) 5.
} 
human and peoples' rights, and more particularly the right to development. ${ }^{22}$ It is not very clear why the right to development was particularly singled out; one could but guess that this was motivated by the high levels of underdevelopment prevalent on the continent. The African leaders could have intended to translate the political obligations assumed by the independent state to champion development into legal obligations based on human rights.

Emphasis on the right to development meant that the OAU was looking beyond merely civil and political rights, though at this stage this could have been unconsciously. One could also argue that emphasis on the right to development was because of the need to create a sort of bulwark against continued economic exploitation by the former colonial powers and to the redress exploitation that had taken place. ${ }^{23}$ Addressing the meeting of experts who convened in Dakar to sketch the way forward for an African human rights instrument, President Senghor of Senegal indicated that the right to development deserved a particular place because it embraced all socio-economic rights as well as civil and political rights. ${ }^{24}$ It is in line with this call that the African Charter was drafted.

\section{The African Charter: A leap beyond ideological cleavages}

Although the African Charter was adopted at the height of the Cold War, it was able to surmount the ideological disputes that had led to socio-economic rights being condemned to an inferior status. ${ }^{25}$ The African Charter was able to proclaim that civil and political rights and socio-economic rights are indivisible. This portrayed Africa as offering 'ripe ground for challenging the universality of international law principles'. ${ }^{26}$

Senghor's message played a very important role in guiding the drafters; when the Charter was adopted at the Eighteenth Assembly of

22 AHG/Dec 115 (XVI) Rev 1 'Decision on Human and Peoples' Rights in Africa', 16th ordinary session of the OAU Assembly of Heads of State and Government, Monrovia, Liberia 1620 July 1979. The resolution called upon the OAU Secretary General to organise, as soon as possible, a restricted meeting of highly qualified experts to prepare a preliminary draft of the African Charter.

23 I would like to acknowledge Prof Sandra Liebenberg for drawing this argument to my attention.

24 Address delivered by Mr Leopold Sedar Senghor, President of Senegal, OAU DOC CAB/LEG/67/5; Ouguergouz (n 16 above) 41.

25 See $C$ Odinkalu 'Implementing economic, social and cultural rights under the African Charter on Human and Peoples' Rights' in M Evans \& R Murray The African Charter on Human and Peoples' Rights: The system in practice, 19862000 (2002) 181.

26 R Murray The African Commission on Human and Peoples' Rights and international law (2000) 11. 
Heads of State and Government, 24 to 28 June 1981 in Nairobi, socioeconomic rights appeared along side civil and political rights without any distinction. Indeed, the African Charter proclaims that: ${ }^{27}$

[I]t is ... essential to pay particular attention to the right to development and that civil and political rights cannot be dissociated from economic, social and cultural rights in their conception as well as universality ... that the satisfaction of economic, social and cultural rights is a guarantee for the enjoyment of civil and political rights.

This is a fundamental leap away from the ideological differences that had proclaimed that civil and political rights were pure rights while socio-economic rights were inferior rights. Literally, one could interpret the preamble as suggesting that civil and political rights are dependent on socio-economic rights without a reverse statement. As I have suggested elsewhere, ${ }^{28}$ socio-economic rights and civil and political rights are symbiotic - they depend on each other in a two way manner. In spite of this, civil and political rights continue to be hoisted above socioeconomic rights. In the African context it is important that both categories of rights be respected because freedom to vote could be as important to the impoverished African as the right to health. The vote could for instance be used to influence decisions as regards the health system.

The bifurcation of human rights, contrary to the spirit of the Universal Declaration of Human Rights (Universal Declaration), ${ }^{29}$ led to the adoption of two different covenants: the International Covenant on Civil and Political Rights (CCPR), protecting civil and political rights, and the International Covenant on Economic, Social and Cultural Rights (CESCR), protecting socio-economic rights.

According to Scott and Macklem, the split was not influenced by the view that socio-economic rights are somehow inferior to civil and political rights. 'Rather, social rights were not viewed as justiciable because courts, or court-like bodies, were not thought to be competent bodies to deal with them. ${ }^{\prime 30}$ A reporting mechanism, and not a complaints procedure, was considered most suitable for enforcement of socio-economic rights. ${ }^{31}$ When one examines the arguments that have been advanced to oppose socio-economic rights, some of them question

27 Preamble, para 8.

28 C Mbazira 'A path to realising economic, social and cultural rights in Africa? A critique of the New Partnership for Africa's Development' (2004) 4 African Human Rights Law Journal 35.

29 Adopted and proclaimed by General Assembly Resolution 217 A(III) of 10 December 1948.

30 C Scott \& P Macklem 'Constitutional ropes of sand or justiciable guarantees? Social rights in a new South African Constitution' (1992) 141 University of Pennsylvania Law Review 89.

$31 \mathrm{~K}$ Arambulo Strengthening the supervision of the International Covenant on Economic, Social and Cultural Rights: Theoretical and procedural aspects (1999) 26. 
the fabric of socio-economic rights as rights. ${ }^{32}$ However, these arguments are misconceived; socio-economic rights also engender negative obligations and civil and political rights engender positive obligations as well. ${ }^{33}$ It is also true that the implementation of civil and political rights, just like the socio-economic rights, requires resources. ${ }^{34}$

\section{Normative content of the African Charter}

The African Charter guarantees a broad range of socio-economic rights. Although some of the Charter's provisions mirror CESCR, there are significant differences between these instruments. While CESCR requires 'progressive realisation' of socio-economic rights subject 'to the maximum of the available resources', the African Charter does not. Article 1, which appears to be definitive of the broad nature of the obligations of states, merely provides that:

The member states of the [African Union] parties to the present Charter shall recognise the rights, duties and freedoms enshrined in this Charter and shall undertake to adopt legislative and other measures to give effect to them.

This provision raises a number of issues. On its literal interpretation it appears to suggest the view that the realisation of all the rights in the African Charter, including socio-economic rights, are not subject to any conditions. The provision has in fact led some commentators to state that except for the right to health, the obligations in respect of other socio-economic rights are stated as being immediate. ${ }^{35}$ This position appears very attractive in reaction to the view that socio-economic rights are not human rights. In fact, the Commission itself appears to have been tempted to adopt this position when it stated that although it was aware of Africa's economic difficulties all rights have to be implemented immediately. ${ }^{36}$ However, the perception of the immediacy of the rights in the African Charter raises one question: Considering Africa's economic circumstances, is it practicable to realise all the socioeconomic rights immediately? The answer is a definite no. While some

32 M Cranston What are human rights? (1973) as quoted by Arambulo (n 31 above) 58; see also C Orwin \& T Pangle 'The philosophical foundation of human rights' in F Plattner (ed) Human rights in our time Essays in memory of Victor Baras (1984) 16.

33 M Sepúlveda The nature of the obligations under the International Covenant on Economic, Social and Cultural Rights (2003) 125126.

34 P Alston \& G Quinn 'The nature and scope of states parties' obligations under the International Covenant on Economic, Social and Cultural Rights' (1987) 8 Human Rights Quarterly 172; see also A Eide 'Realisation of social and economic rights and the minimum threshold approach' (1989) 10 Human Rights Law Journal 41; In re Certification of the Constitution of the Republic of South Africa 199610 BCLR 1253 (CC).

35 Odinkalu (n 25 above) 196.

36 Presentation of the Third Annual Activity Report by Prof Umozurike, Chairperson of the African Commission to the 26th Assembly of Heads of State and Government of the OAU, 911 July 1990. 
levels of the obligations, such as respect, may be realised immediately, the protection, promotion and fulfilment of socio-economic rights requires substantial resources. Many, if not all, African states have very poor economies riddled by corruption, poor planning and insignificance in the global economy save as consumers. It is hard for such economies to immediately overcome their structural problems and to marshal the resources necessary to provide for all socio-economic needs immediately. At best, human rights obligations should compel the African leaders to ensure that they do whatever is reasonable to improve the resources necessary for socio-economic rights realisation and to utilise the available resources maximally.

Though civil and political rights too require resources to protect, promote, and fulfil, ${ }^{37}$ generally there are significant differences in the levels of resource required between the two categories of rights. It is therefore does not come as a surprise that even countries endowed with economic resources are yet to fully realise socio-economic rights and have always raised the defence of resources. ${ }^{38}$ On this note I agree with Nmehielle that the debate on the justiciability of socio-economic rights under the Charter should not assume an extreme posture. ${ }^{39}$ It is important that the socio-economic rights in the African Charter be realised progressively due to the underdevelopment of most African countries, ${ }^{40}$ though states have to begin taking immediate measures. In addition to Africa's underdevelopment, it is also important that socioeconomic rights be realised progressively because the standards for their full realisation are dynamic; they are defined by changing socioeconomic circumstances and establish shifting standards. This is because peoples' standards must improve on a continuous basis. There is no stage at which one can say that the zenith of human socio-economic development has been reached.

\subsection{Socio-economic rights in the African Charter}

The African Charter protects a broad range of socio-economic rights and also a number of collective rights relevant to socio-economic rights. Some of the collective rights have elements that are directly relevant to socio-economic rights. In this respect, the African Charter serves a good purpose by not making distinctions on the basis of the outdated generational description of rights. The rights include

\footnotetext{
37 See Constitutional Court of South Africa in In re Certification of the Constitution of the Republic of South Africa (n 34 above).

38 Eg, see the Canadian case of Eldridge \& Others $v$ British Columbia \& Others (Attorney General) [1997] 3 SCR 624, 151 DLR (4th) 577.

39 Nmehielle (n 11 above) 124

40 Ankumah (n 14 above) 144.
} 
equitable and satisfactory conditions of work, ${ }^{41}$ right to health, ${ }^{42}$ right to education, ${ }^{43}$ protection of the family, ${ }^{44}$ right to self-determination, ${ }^{45}$ right to dispose of wealth and natural resources, ${ }^{46}$ right to economic, social and cultural development, ${ }^{47}$ right to peace, ${ }^{48}$ and right to a satisfactory and favourable environment. ${ }^{49}$

It is not my intention to discuss the normative content of each of these rights as this has been covered adequately by a number of authors. ${ }^{50}$ But just to point out a few things, some of these rights are drafted along the same lines as CESCR. However, some distinctions can be registered. A number of rights such as development are not protected in CESCR though recognised by the UN. ${ }^{51}$ Provisions on rights such as health and work are not as extensively drafted as their counterparts in CESCR. In spite of this, their construction could still lead to their understanding in an extensive manner.

The difference between the African Charter and CESCR reflects a desire on the part of the drafters of the former to produce an exclusively African instrument. They could have copied and reproduced the provisions of CESCR and CCPR in the area of civil and political rights. But they chose not to, this is because they wanted to produce a distinctively African instrument elaborating the normative understanding of human rights in the African context. However, the African states are also parties to the global instruments and considerable jurisprudence has been generated on these global instruments. This compels the African Commission, as well as the African Court, to refer to the global instruments and jurisprudence. I will revert to this argument later.

\section{Twenty years of losses and gains: From redundancy to progression and significant strides}

\subsection{The redundancy stage}

The redundancy stage represents a period in time when the African Commission seemed either reluctant or unable to give the rights in

\footnotetext{
Art 15.

Art 16.

43 Art 17.

44 Art 18.

45 Art 20

46 Art 21.

47 Art 22 .

48 Art 23.

49 Art 24

50 See Nmehielle (n 11 above); Ouguergouz (n 16 above); Odinkalu (n 25 above); Murray (n 26 above).

51 See United Nations General Assembly Declaration on the Right to Development GA Res 41/128, Annex, 41GAOR Supp (No 53).
} 
the African Charter their fullest interpretation. ${ }^{52}$ For socio-economic rights, this was exacerbated by the fact that in the initial years not so many complaints invoking socio-economic rights provisions were filed. This redundancy also represents the high degree of apathy exhibited towards socio-economic rights at the international human rights arena. Though theoretically the African Charter emphasises the indivisibility of civil and political rights and socio-economic rights, translating this into practice and transcending the apathy has not been a straightforward path.

Another factor that precipitated the redundancy stage relates to the weaknesses of the African Commission in its initial years of operation. So many factors have been identified as contributing to the ineffectiveness of the African Commission in exercising its mandate. Doubts have been expressed about the independence and impartiality of the members of the African Commission. Since its commencement, a sizeable number of commissioners have simultaneously held posts in the public service of their countries, either as attorneys-general, cabinet ministers or ambassadors. This appears to have compromised their independence and stopped them from condemning their governments.

The effectiveness of the African Commission has also been affected by promotion of confidentiality of its proceedings which has in the past eroded the culture of accountability on its part. ${ }^{53}$ A decision maker who makes a decision, knowing that such decision must be justified, will act more carefully and pay attention to all the relevant issues. ${ }^{54}$ The African Commission has in the past missed the opportunity of being such a decision maker because of its confidentiality. This could be one of the factors why its initial decisions were sloppy as the possibility of public criticism was limited.

The African Commission has also been suffering from resource deficiencies; it was under-funded by the OAU and continues to be underfunded by the AU. This has affected all activities of the Commission, including its capacity to do research and deliver well-reasoned legal opinions. At the moment most of the few technical personnel at the Commission's Secretariat are funded by donors on a periodic basis, and usually leave the Commission at times when their experience becomes most relevant.

The Commission has for a long time been a 'toothless bull-dog', a point I shall revert to later below. Initially, the African Commission was conceived as a promotional institution. The OAU was reluctant to give the Commission a significant protective role. This is reflected in the

\footnotetext{
52 See Ankumah (n 14 above) 2.

53 Art 59(1) of the African Charter provides that all measures taken within the provisions of ch III shall remain confidential until such time as the Assembly of Heads of State and Government shall otherwise decide.

54 See E Mureinik 'A bridge to where? Introduction to the Interim Bill of Rights' (1994) 10 South African Journal on Human Rights 31.
} 
vagueness of the provisions that empower the Commission to entertain and consider individual communications. While the African Charter makes express provisions empowering the African Commission to entertain and consider state complaints, ${ }^{55}$ there are no corresponding provisions in respect of individual complaints. All that the Charter says is that before each session, the Secretary of the Commission shall make a list of the communications, other than those of state parties, and transmit them to the members of the Commission who shall indicate which communications should be considered. ${ }^{56}$ Though the Commission has exploited the vagueness to assert its powers to hear individual complaints, its efforts in this regard have been drawn back by the absence of an effective remedial and enforcement mechanism. ${ }^{57}$

As seen in the next section, all socio-economic rights decisions made by the African Commission during the redundancy stage are inadequate in normative terms. In these decisions, there is no effort on the part of the Commission to draw from international human rights law in the area of socio-economic rights. Most decisions just declare that the state has violated rights without elaborating the normative basis of the right. But we should not pay a blind eye to the fact that at this stage not all communications were properly argued; yet the failure of most states to defend the communications denied the Commission the opportunity to hand down reasoned judgments in a balanced manner. At the same time, one sees communications that were defended, yet they suffer from the same weaknesses from all perspectives.

\subsubsection{Major decisions during the redundancy stage}

The communications discussed under this heading represent the very few that invoked, in one way or another, together with civil and political rights and socio-economic rights provisions in the African Charter. Some common features run through all of them. Apart from consolidating several communications, they are not elaborate; the normative content of the rights is not discussed adequately. Some are not defended by the state, yet in the defended ones there is no elaboration of the legal arguments of the state or of the applicants in the final decision. There does not appear to be adequate legal research put in on the part of the African Commission, justification of findings by authoritative international human rights law sources is lacking. This is so even where in some cases there is international literature, which is also easily accessible, like the standards of treatment of prisoners. ${ }^{58}$ In remedial

\footnotetext{
Art 47.

56 Art 55(1).

57 E Welch 'The African Commission on Human and Peoples' Rights: A five year report and assessment' (1992) 14 Human Rights Quarterly 49.

58 Like the UN Basic Principles for the Treatment of Prisoners, adopted and proclaimed by General Assembly Resolution 45/111 of 14 December 1990.
} 
terms, other than make simple declarations of violation of rights, the African Commission does not make any substantive recommendations to remedy the violations.

In Free Legal Assistance Group $v$ Zaire, ${ }^{59}$ it was alleged that the mismanagement of public finances, the failure to provide basic services, the shortage of medicines and closure of schools and universities was a violation of the African Charter. ${ }^{60}$ In finding that there was a violation of the right to health, the African Commission regurgitates article 16 of the African Charter and without explanation concludes that there is a violation of the Charter. ${ }^{61}$ The Commission also held that the failure of the government to provide services such as safe drinking water and electricity and the shortage of medicines also amounted to violation of the right to health. One could read the Commission here as saying that the right to health gives rise to such rights as water and electricity, rights not expressly protected by the Charter. However, the scanty nature of the decision does not give chance for concrete imputation on the Commission of this position. Also, in an unelaborated manner, the Commission concluded that the closure of universities and secondary schools constituted a violation of the right to education in article $17 .{ }^{62}$ It is, however, apparent from the operative part of the decision that the Commission did not formally hold that article 17 had been violated.

It has been argued that this communication appears to impose on the state the obligation to fulfil socio-economic rights, though it does this in a terse manner. ${ }^{63}$ The Commission should have seized the opportunity to elaborate on the right to education, especially considering the fact that article 17 does not detail the content of this right. This is in comparison to article 13 of CESCR, which details the right as comprising of compulsory and free primary education and access to secondary and higher education.

The above communication may be contrasted with the slightly elaborate Union Interafricaine des Droits de I'Homme and Others v Angola, ${ }^{64}$ also touching on the right to education, but also on the right to work. The communication arose from the mass rounding up and expulsion in 1996 of West African citizens from Angola by the government. The Commission found the expulsion, in addition to other rights, to have violated the right to education and the right to work. It was stated that though the Republic of Angola was facing economic difficulties this did

\footnotetext{
(2000) AHRLR 74 (ACHPR 1995).

Para 4.

1 Para 47.

62 Para 48.

63 F Viljoen 'The justiciability of socio economic and cultural rights: Experience and problems' (unpublished paper on file with author) 23.

64 (2000) AHRLR 18 (ACHPR 1997).
} 
not justify radical measures against non-nationals. ${ }^{65}$ The deportations were found to have called into question such rights as education and the right to work, amongst others. The Commission also held that article 2 of the Charter (non-discrimination) obligates states to ensure that all persons in its territory, nationals or non-nationals, enjoy all the rights guaranteed. ${ }^{66}$ But again the communication falls short of an elaboration of the right to education and how it became applicable to the applicants. This could be associated with the scanty nature of the facts and the failure of the Commission to interrogate them fully.

In International Pen and Others (on behalf of Saro-Wiwa) v Nigeria, ${ }^{67}$ the right to health was brought into issue. The communication, a consolidation of four communications, ${ }^{68}$ arose from the detention of Ken Saro-Wiwa, a writer and Ogoni rights activist, together with others. They had been detained by the Nigerian Abacha government following the death of four people and consequent riots in the oil producing region of Ogoniland. The detainees were tried by a military tribunal and sentenced to death. In spite of interim measures adopted by the Commission pending the disposal of the communication, the 'convicts' were executed on 10 November $1995 .{ }^{69}$ It was alleged that while in detention Saro-Wiwa had been severely beaten and in spite of his high blood pressure, had been denied access to medicine and a doctor. ${ }^{70}$

Without elaboration of the content of the right to health, the African Commission held that the responsibility of the state in respect of the right to health is heightened when a person is in detention. In such cases a person's integrity and wellbeing are completely dependent on the state. It was declared that the denial of access by Saro-Wiwa to a qualified doctor was a violation of article 16 of the African Charter. ${ }^{71}$ Again, the decision is not elaborate. In spite of this, however, it is important in as far as it states that prisoners enjoy special protection and are wholly dependent on the state for their wellbeing. In Africa, as well as other parts of the world, prisoners are ostracised and removed from society. They are considered moral outcasts not worthy of protection or entitled to any human rights. The African Commission and the African Court could, in future, build on this case to elaborate on the health rights of prisoners and to redeem them as moral beings entitled to live as wholesome humans.

The massive violation of prisoners' socio-economic rights is seen again in Malawi African Association and Others v Mauritania, ${ }^{72}$ also con-

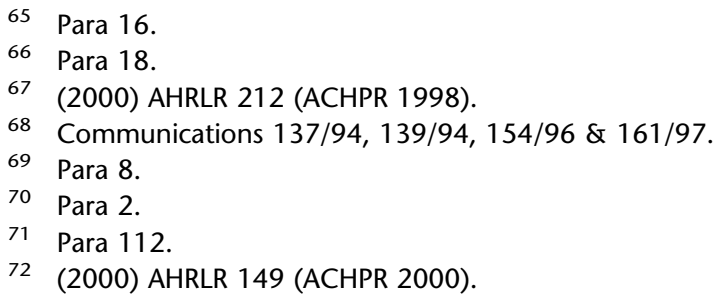


solidating several communications. In reaction to popular disapproval of racial marginalisation of black people in the country, the government detained hordes of people under the most inhumane conditions. The prisoners, who had survived execution, were denied adequate food and medical attention, and as a result some had died in detention. Their cells were infested with bedbugs, lice and cockroaches. The prisoners slept in overcrowded cells on dirty floors without any blankets. ${ }^{73}$ Again, the communication, in a shorthand manner, restates the responsibility of the state towards prisoners as regards their right to health. ${ }^{74}$ The African Commission hastily, and without further elaboration, condemned the conditions of detention under article 5, which prohibits torture and degrading treatment or punishment. ${ }^{75}$ One would have expected the Commission to give a detailed elaboration of the obligations of states towards prisoners in relation to their socio-economic rights and to refer to international standards in this respect.

\subsubsection{The progression stage}

The progression stage, which is the current stage, represents a time when the African Commission has began to surmount some of its weaknesses and to proclaim socio-economic rights in a more progressive manner. This stage is highlighted by two important decisions: Social and Economic Rights Action Centre (SERAC) and Another $v$ Nigeria (SERAC case) $^{76}$ and Purohit and Another $v$ The Gambia (Purohit case). ${ }^{77}$ In these cases, discussed later in detail, the African Commission has given normative content to some of the socio-economic rights in the African Charter. The Commission has even gone ahead to read into the Charter rights which are not expressly protected, such as rights to food and shelter. The decisions also indicate increased reliance on standards established by international human rights in the area of socio-economic rights. In remedial terms, these decisions make clear and elaborate recommendations that transcend the declaratory nature of the Commission's recommendations in previous cases.

The Purohit case, contrary to perceptions that the socio-economic rights obligations in the African Charter are immediate, has defined the obligations in a realistic manner, taking into account the resource constraints of African countries. This has brought the Charter very close to CESCR. I have argued elsewhere that this is very important in as far as it seeks to marry the regional human rights system with the international system. ${ }^{78}$ This is very important, considering especially the position of the

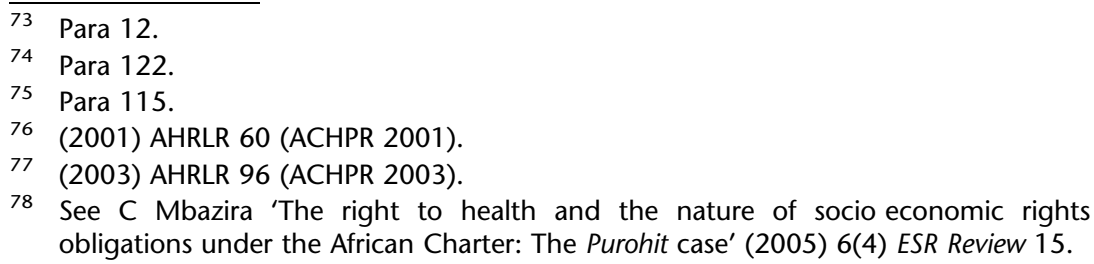

78 See C Mbazira 'The right to health and the nature of socio economic rights obligations under the African Charter: The Purohit case' (2005) 6(4) ESR Review 15. 
African Court with its jurisdiction to apply international instruments ratified by the state. I will elaborate this point later. The Commission's progression has been driven by a number of factors. One of the factors is its increased co-operation with human rights organisations both within and outside Africa. Non-governmental organisations (NGOs) have played a very important role, not only in filing communications, but also in prosecuting them in a professional manner. NGOs have also been sponsoring interns to provide technical assistance to the Commission. The NGOs have, on so many occasions, during the ordinary sessions of the Commission, brought to the fore some of the human rights problems in Africa. They have made statements, submitted research reports and draft resolutions. All of these have helped in advancing the normative understanding of the rights in the Charter. Some organisations with academic roots, such as the Centre for Human Rights at the University of Pretoria, have engaged in high-level research on the African human rights system and also trained students in the field. This has increased academic knowledge and literature on the system.

However, in spite of the tremendous achievements realised at the progression phase, a number of obstacles still have to be surmounted. Full integration of the international human rights law standards is yet to be realised. The weaknesses of the enforcement mechanisms are still an impediment to the effectiveness of the African Commission. The Commission continues to be under-funded and is still understaffed.

\subsubsection{Major decisions during the progression phase}

As already stated, the phase of progression is punctuated by two major decisions, SERAC and Purohit. The difference between these decisions and those during the redundancy phase is, first, the African Commission appears to have invested some research in writing the decisions. Secondly, they are elaborate in the rights they protect. The SERAC case goes as far as reading into the African Charter rights not explicitly protected. Thirdly, there is some reference to international human rights jurisprudence in the area of socio-economic rights at the UN level. In remedial terms, the Commission goes beyond making declarations of violations of rights; it makes comprehensive recommendations of things that have to be done to remedy the violation. Recommendations include the repeal of legislation and the appointment of a commission of inquiry and keeping the African Commission posted on the measures adopted after the decision.

It could be argued that in these cases the Commission did not hesitate to make far-reaching recommendations because it knew that their legitimacy would not arise since the decisions of the Commission have persistently been ignored. The governments would then find it easy to be indulgent to the recommendations since they are considered to be 
inconsequential. ${ }^{79}$ Indeed, as argued later, there is no evidence that either SERAC or Purohit have been implemented. Of course it may be too early to judge the implementation of Purohit.

The SERAC case arose from the exploitation of oil resources by the Nigerian government, in partnership with Shell, in disregard of the environment and health of the Ogoni people. The Nigerian government had neither required environmental impact assessments nor enforced an effective regulatory mechanism. The oil activities had led to illnesses arising from environmental degradation. People's protests had been met with un-proportionate and brutal military force placed at the disposal of Shell by the Nigerian government. Thousands of people were evicted from their homes, their homesteads and farms destroyed and livestock killed, leading to malnutrition and starvation.

Before going into the merits of the case, the African Commission discussed, in general terms, the nature of the socio-economic rights obligations engendered by the African Charter. Consistently with the ideas of Shue, ${ }^{80}$ and as used by the UN Committee on Economic, Social and Cultural Rights (Committee), the Commission stated that the rights 'generate at least four levels of duties, namely the duty to respect, protect, promote and fulfil'. 'These obligations', according to the Commission, 'universally apply to all rights and entail a combination of negative and positive obligations. ${ }^{81}$ The Commission then explained each of the levels and in the context of article 2(1) of CESCR held that sometimes the need to enjoy some of the rights requires concerted action from the state in terms of more than one of the duties above. $^{82}$ These pronouncements, together with the statement that there is no right in the African Charter that could not be made effective, have been described as underscoring the justiciability and commitment to enforce socio-economic rights by the African Commission. ${ }^{83}$

The Commission found that the actions of the Nigerian government violated the right to a clean and healthy environment. This right, said the Commission, requires the state to take reasonable legislative and other measures to prevent pollution and ecological degradation, promote conservation and to secure an ecologically sustainable development and use of resources. ${ }^{84}$ The Commission also referred to article 12 of CESCR and said that the government was under a duty to improve all aspects of the environment, including industrial hygiene.

The Commission also found the state to have violated the right to health. This right was linked to the right to a clean and healthy envir-

\footnotetext{
79 These arguments were brought to my attention by Prof Liebenberg and I acknowl edge her in this respect.

80 H Shue Basic rights: subsistence, affluence, and US foreign policy (1980).

$81 \mathrm{n} 7$ above, para 44.

82 Para 48.

83 Viljoen (n 63 above) 23.

84 n 7 above, para 52.
} 
onment, which at best required the government 'to desist from carrying out or sponsoring or tolerating any practice, policy or legal measures violating the integrity of the individual' ${ }^{85}$ Compliance with these two rights, according to the Commission, must also include ordering, or at least permitting, independent scientific monitoring of the environment, and requiring and publicising of environmental and social impact studies. ${ }^{86}$ The government of Nigeria had defaulted on all these.

The Commission condemned the failure of the government to protect its people from third party activities. The government had in fact, instead, facilitated Shell's violations by lending it its military power, contrary to the African Charter and international obligations. ${ }^{87}$ Further to this, the Commission declared that there was a violation of the right of peoples to dispose of their wealth. ${ }^{88}$ In my opinion, it is necessary to protect the peoples' right to development, especially in the context of increased globalisation of exploitation of natural resources without regard to peoples' rights. The right to dispose of wealth should be linked to the right of peoples to self-determination and their capacity to resist exploitation in the cultural context should be strengthened. ${ }^{89}$

The most innovative stance by the Commission is its reading into the Charter of the rights to shelter and food, rights which are not explicitly protected by the Charter. According to the Commission, the right to food is implicitly recognised in such provisions as the right to life, the right to health and the right to economic, social and cultural development, which are expressly recognised under the Charter. This right, held the Commission, is inseparably linked to the dignity of human beings and is therefore essential for the enjoyment and fulfilment of such other rights as health, education, work and political participation. 90

Like the right to food, the Commission held that the right to housing or shelter is implicitly recognised by the Charter. It reasoned that this right could be derived from a combination of the provisions protecting the right to health, the right to property, and the protection accorded to the families. The Commission noted that the destruction of houses adversely affects people's property, their health and families. Furthermore, shelter means more than a roof over one's head. It embodies the

85 As above.

86 Para 53.

87 Para 58.

88 Para 55.

89 See J Oloka Onyango 'Who is watching "Big Brother"? Globalisation and the protection of cultural rights in present day Africa' (2005) 5 African Human Rights Law Journal 1.

90 n 7 above, paras 6567. 
right to be left alone and to live in peace - whether under a roof or not. $^{91}$

Regarding remedies, the Commission made extensive recommendations. It recommended that investigations be conducted, those responsible for violations prosecuted and compensation paid to those who had suffered. The Commission also recommended that an environmental and social impact assessment be carried out. The government was urged to keep the Commission posted on the measures undertaken to solve the problem. ${ }^{92}$ These are perhaps the most comprehensive recommendations made by the Commission up to that date, which, if enforced, would have gone a long way in vindicating the rights that had been violated. The recommendations, if implemented, would have also deterred future violations and established a relationship of trust between the government and the people. Unfortunately, there is no evidence that these recommendations were taken seriously by the government. The recommendations, when read together with the findings on merit, lead one to conclude that the Commission can make very strong declarations of rights and still move to establish a constructive dialogue with the state on implementation of its recommendations. However, the success of this move is dependent on the state's willingness to engage, in good faith, in such a post-decision dialogue.

The Purohit case was filed by two mental health advocates, on behalf of mental patients at a psychiatric unit in The Gambia, and existing and future mental health patients detained under the mental health laws of the Republic of The Gambia. The complainants alleged that the provisions of the Lunatic Detention Act and the manner in which mental patients were treated amounted to a violation of various provisions of the African Charter, including the right to health. It was alleged that the Act failed to provide safeguards for patients who were (suspected of being) insane during their diagnosis, certification and detention. Among other things, it did not make provision for either review or appeal against orders of detention and there was no remedy for erroneous detentions. No provision existed; it was argued, for the independent examination of the administration, management and living conditions within the unit itself.

In a rare feat, the Commission began by lambasting states for their failure to defend communications. In spite of repeatedly having been

91 See paras 6064 . I have argued elsewhere that within the African context, there is a strong link between the right to food and the right to shelter. Most African communities survive on subsistence agriculture. Food sources are often close to their houses. Some societies ensure food security by storing and preserving the excess of their harvest in granaries, constructed with traditional techniques. Others plant crops in such a manner that some mature before others, in order to ensure a steady supply of food. Forced evictions and the denial of access to housing interfere with this process; C Mbazira 'Reading the right to food into the African Charter on Human and Peoples' Rights' (2004) 5(1) ESR Review 5.

92 n 7 above, para 71. 
given time to file its response, the government of The Gambia filed its submissions only two days before the consideration of the communication. The Commission stated that when states accede to international instruments, they do so voluntarily and that having to make several requests to states to file their submissions is troubling. According to the Commission, this practice 'not only seriously hampers the work of the African Commission, but it also defeats the whole purpose of the African Charter'. ${ }^{93}$ The Commission was especially perturbed by the fact that the Secretariat of the Commission is situated in The Gambia.

On the merits, the Commission found The Gambia to be in violation of a range of African Charter rights. It held that the Lunatic Detention Act was discriminatory because the categories of people who would be detained under it were likely to be people picked up from the streets and people from poor backgrounds. ${ }^{94}$ Secondly, it was held that the legislative scheme of the Act, its implementation and the conditions under which persons were detained amounted to a violation of respect for human dignity. Among other things, the Act used such terms as 'idiots' and 'lunatics' to describe persons with mental illness. Such terminology, according to the African Commission, was dehumanising. ${ }^{95}$

On the right to health, the Commission held that the enjoyment of this right is vital to all aspects of a person's life and wellbeing and is crucial to the realisation of all other rights. It held that this right requires 'the right to health facilities, access to goods and services to be guaranteed to all without discrimination of any kind'. ${ }^{96}$ The Commission held that mental health patients deserve special treatment because of their condition and by virtue of their disability, they should be enabled not only to attain but also sustain their optimum level of independence and performance. ${ }^{97}$

The Lunatic Detention Act was found to be deficient in terms of its therapeutic objectives and the provision of matching resources and programmes for the treatment of persons with mental disabilities. ${ }^{98}$ The Commission relied heavily on the UN Principles for the Protection of Persons with Mental Illness and Improvement of Mental Care (Principles). ${ }^{99}$ The Principles accord special treatment to mental health patients and stress that such patients are entitled to the highest standards of medical care at three levels: analysis and diagnosis, treatment and rehabilitation. However, the Commission took note of the difference in standards between the Principles and the African Charter. While

93 n 7 above, para 41.

94 Para 53.

95 Para 59.

96 Para 80.

97 Para 81.

98 Para 83.

99 Adopted by UN General Assembly Resolution 46/119, December 1991. 
article 16 uses 'best attainable state of mental health', the Principles use 'highest attainable standards'. But this was not viewed by the Commission as a bar to the application of the Principles, as there was nothing to suggest that elaborating the right in the Charter in the direction of the Principles was deficient.

The Commission took note of the relevance of resources and the realities facing African countries in their efforts to realise the right to health. According to the Commission: ${ }^{100}$

[M]illions of people in Africa are not enjoying the right to health maximally because African countries are generally faced with problems of poverty which renders them incapable to provide the necessary amenities, infrastructure and resources that facilitate the full enjoyment of this right. Therefore, having regard to this depressing but real state of affairs, the African Commission would like to read into article 16 the obligation on the part of states party to the African Charter to take concrete and targeted steps, while taking full advantage of its available resources, to ensure that the right to health is fully realised in all its aspects without discrimination of any kind.

The finding above establishes the fact that the availability of resources is a relevant factor when determining whether a state is in violation of the socio-economic rights in the African Charter. This case suggests that the African Commission is leaning towards adopting standards the Committee has developed in its General Comments on the socio-economic obligations under CESCR, especially General Comment No 3. ${ }^{101}$ As noted earlier, socio-economic rights under CESCR are realisable progressively to the maximum of a state's available resources. The Committee has interpreted this to mean that state parties must not take retrogressive measures that have a negative impact on existing access to socio-economic rights. It has also stated that states must comply with minimum essential levels of socio-economic rights.

The approach adopted by the African Commission is justifiable, given that the formulation of the rights in the African Charter is not substantially different from that of CESCR. There is apparently no reason why Africa should adopt a different standard, and one which appears to be idealistic and out of touch with reality. In addition, CESCR has been interpreted by the Committee in a manner that considers the position of poor countries. For example, the Committee has held that states seeking exemption from liability for not meeting their socio-economic rights obligations on the ground of a lack of resources must demonstrate that they have used the available resources to satisfy minimum essential levels of socio-economic rights as a matter of priority. ${ }^{102}$

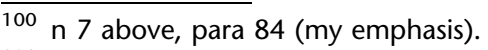

101 Committee on Economic, Social and Cultural Rights, General Comment No 3, The nature of state parties' obligations (5th session, 1990) UN Doc E/1991/23, annex III 86 (1991), reprinted in Compilation of General Comments and General Recommendations Adopted by Human Rights Treaty Bodies, UN Doc HRI/GEN/1/Rev 6 at 14 (2003).

102 n 101 above, para 10.
} 


\subsection{The phase of significant strides: The African Court on Human and Peoples' Rights}

The commencement of operations by the African Court and its delivery on socio-economic rights in my opinion represent a phase I would describe as the phase of significant strides. Considering the calibre of the persons that have been elected the first judges of the African Court, and considering their experience in the area of international law, one hopes that they will deliver quality judgments. ${ }^{103}$ The jurisprudence of the African Court in the area of socio-economic rights is likely to have an indelible impact on the African continent and to inspire the African Commission and domestic courts. Contrary to belief that the African Court will undermine domestic courts by establishing an extra-territorial jurisdiction, ${ }^{104}$ the Court will strengthen human rights in all African countries.

The African Court is empowered to apply the African 'Charter and any other relevant human rights instruments ratified by the states concerned' as one of its sources of law. ${ }^{105}$ This is different from the African Charter, which merely authorises the African Commission to seek inspiration from international human rights law. ${ }^{106}$ This new move is crucial as it seeks to integrate the global human rights system and the regional system. This means that the Court will have to apply the standards of CESCR, in respect of states that have ratified it. But as I have argued elsewhere, this integration presents a challenge to the African Court because of the problem of permeability. ${ }^{107}$ Most international treaties have their own monitoring bodies, which have interpreted and applied such treaties. Inconsistent interpretation by other bodies not charged with the implementation of a treaty may have fatal results. Additionally, while there is a need for inspiration to be sought from international human rights law, there is also the need to maintain the identity of regional human rights treaties and to allow them to address peculiar regional issues.

103 The Judges elected by the Executive Council of the AU on 21 January 2006 include: Sophia Akuffo (Judge of the Supreme Court of Ghana); Fanoush Hamid Faraj (Member of the Supreme Council of Justice Authority, Libya); Guindo Modibo Tounty (Judge of First Instance of Timbukutu, Mali); Guisse El Hadji (Former Presiding judge of the Court of Appeal of Senegal); George Kanieyamba (Justice of the Supreme Court of Uganda); Kelello Mafoso Guni (Judge of the High Court of Lesotho); Jean Ngabishma Mutsinzi (Judge of the Supreme Court of Rwanda); Bernard Ngoepe (Judge President of the Transvaal Provincial Division, South Africa); Gérard Niyungeko (Professor of Law, University of Burundi); Fatsa Ouguergouz (Secretary of the ICI, The Hague); and Jean Emile Somda (Member of the Constitutional Court, Burkina Faso).

104 See NB Pityana 'Reflections on the African Court on Human and Peoples' Rights' (2004) 4 African Human Rights Law Journal 121124.

105 Art 7 (my emphasis).

106 Art 60.

107 Mbazira (n 78 above) 17. 
However, unless a situation presents absolutely peculiar circumstances, the universality of human rights should be promoted by the interpretation of regional treaties in a manner consistent with international human rights law. I have argued that this could be achieved if the regional and international instruments are married. This would make it possible to apply the norms proclaimed by universal standards without making the international treaty a primary source of law. ${ }^{108}$ The marrying process would integrate the instruments in a manner that does not collapse the norms of one into another. In this, the normative nature of the regional instruments would be enhanced, while at the same time preserving their identity. Unless there is evidence of a need for a divergent interpretation, the African Court will have to interpret the provisions of the African Charter in a manner that is consisteny with international law. This is not an easy task in the African Court's enterprise of redeeming the poor.

However, there are still some very important challenges that the African Court should face in its attempts to actualise the rights in the African Charter. The most important challenge is to overcome the problem of non-enforcement of the judgments of the Court, as discussed in the next section.

\subsubsection{Enforcement of judgments}

The success of the way into the phase of significant strides is, amongst others, dependent on whether the African states respect and execute the judgments of the African Court. The implementation of the recommendations of the African Commission leaves a lot to be desired. The recommendations have been ignored, not only by the state parties but also by the AU Assembly of Heads of State and Government. Prominent incidents include the stay of execution communications ignored, in a flagrant manner, by some African states. Examples include the execution of Ken Saro-Wiwa by the Nigerian government in 1995 in spite of a note verbale from the African Commission that the execution be halted until the case has been heard by the Commission. ${ }^{109}$ Another example is the 2001 execution of Mariette Bosch by Botswana authorities only four days after the African Commission communicated its appeal for a stay. ${ }^{110}$ In the area of socio-economic rights, in spite of the good recommendation of the African Commission in the SERAC case, Ogoniland still experiences massive exploitation of oil in a manner that is detrimental to the people. This could only mean that the recommenda-

\footnotetext{
108 As above.

109 n 67 above.

110 See L Chenwi 'Towards the abolition of the death penalty in Africa: A human rights perspective' unpublished LLD thesis, University of Pretoria, 2005 178; see also L Chenwi 'The African Commission and the death penalty' (2005) 11 Amicus Journal 13.
} 
tions of the Commission have not been implemented by the Nigerian government.

Theoretically, the problems of the enforcement mechanism have been surmounted by the enforcement procedures provided to the African Court. The African Court Protocol enjoins state parties to comply with the judgments of the African Court. By ratifying the Protocol, the parties guarantee execution of the judgments. ${ }^{111}$ The AU Council of Ministers is also enjoined to monitor execution of judgments of the Court on behalf of the AU Assembly. ${ }^{112}$ The Court's remedial mandate is not restricted to making recommendations, but extends to ordering 'payment of fair compensation or reparation'. ${ }^{113}$ Additionally, in cases of extreme gravity and urgency, and when necessary to avoid irreparable harm to persons, the Court is empowered to adopt such provisional measures as it deems necessary. ${ }^{114}$ What remains to be seen, however, is whether this is going to be operationalised. This is because the enforcement of decisions of international tribunals has always been a problem in international law.

It is important to note that the enforcement of the decisions of the African Court at the domestic level is not going to be an easy task. The Protocol of the Court anticipates a reliance on good faith implementation on the part of the state. All it does is to require states to guarantee execution of the judgments of the Court. ${ }^{115}$ Although the Court may report to the AU Assembly cases which have not been executed, ${ }^{116}$ history shows us that the AU Assembly has always been very reluctant to punish its members. While the Protocol compels the Council of Ministers of the AU to monitor compliance with the judgment on behalf of the Assembly, ${ }^{117}$ it is likely that the Council will await instructions from the Assembly.

Without being pessimistic, it is unlikely that African states will enforce the judgments in good faith. It is advisable that in its initial years, the African Court should concentrate on influencing domestic courts. This is because the domestic courts are closer to the people and closely linked to domestic enforcement mechanisms; their role is likely to have a bigger impact in comparison with the African Court - whose enforcement mechanism may be somewhere in Addis Ababa.

Influencing the decisions of the domestic courts will also forestall countermajoritarian accusations against the African Court. While the countermajoritarian dilemma has been predominantly domestic, there

\footnotetext{
111 Art 30.

112 Art 29(2).

113 Art 27(1).

114 Art 27(2).

115 Art 30.

116 Art 31.

117 Art 29.
} 
is evidence that it is being taken to the international stage. ${ }^{118}$ Countermajoritarian objections have been especially intense in respect of enforcement of socio-economic rights because of their impact on government policy and resources. With the proliferation of international courts having a wide mandate, questions may be asked about their legitimacy to direct domestic affairs in a manner that is inconsistent with the wishes of the people. These concerns would be obviated if the domestic courts assume the role of translating international norms into domestic law using the jurisprudence of international courts. The domestic courts have confronted the countermajoritarian dilemma and appear to be succeeding in establishing appropriate balances. Establishing such balances may be hard for international tribunals because they operate outside the political contexts of a country and yet their intervention is occasional.

\section{Conclusion}

The last 20 years of the African Charter have been mixed with losses and gains in the area of socio-economic rights. In spite of the initial frustration of the African Commission with respect to enforcing the rights in the African Charter, there is evidence that some gains have been made in the area of socio-economic rights. The watershed decisions of SERAC and Purohit have gone into some detail in elaborating the nature of the obligations engendered by the socio-economic rights provisions of the African Charter. Though the Commission's enforcement mechanisms remain weak, this void has, to a certain extent, been filled with the establishment of the African Court. The Court has been given a wide mandate and powers to issue binding judgments. What remains to be done by the Court in the area of socio-economic rights is to pick up from the gains of the Commission and to propel socio-economic rights into the phase of significant strides.

Some obstacles, however, still have to be surmounted if the operation of the Court and its judgments are going to have an impact. The biggest obstacle is the enforcement of the judgments of the Court. In its initial years of operation, the Court should aim at developing a jurisprudence which has the capacity to influence the judgments of domestic courts. This is because the domestic courts are close to the enforcement mechanisms and are also likely to be able to issue more meaningful and enforceable remedies.

118 See R Alford 'Misusing international sources to interpret the Constitution' (2004) 98 American Journal of International Law 57. 